\title{
Spatial Analysis and Population Dynamics of Haplaxius crudus (Hemiptera: Cixiidae) in Coconut Amazon
}

\author{
Lucas Faro Bastos ${ }^{1}$, Artur Vinícius Ferreira dos $\operatorname{Santos}^{1}$, Fernanda Valente Penner ${ }^{1}$, \\ Lizandra Maria Maciel Siqueira ${ }^{1}$, Anderson Gonçalves da Silva ${ }^{2}$, Ivan Carlos Fernandes Martins ${ }^{3}$, \\ Paulo Manoel Pontes Lins ${ }^{4} \&$ Telma Fátima Vieira Batista ${ }^{1}$ \\ ${ }^{1}$ Institute of Agrarian Sciences, Department of Plant Biology and Phytosanity, Universidade Federal Rural da \\ Amazônia, Belém, PA, Brazil \\ 2 Grupo de Estudos em Manejo Integrado de Pragas, Universidade Federal Rural da Amazônia, Campus \\ Paragominas, Paragominas, PA, Brazil \\ ${ }^{3}$ Universidade Federal Rural da Amazônia, Campus Capanema, Capanema, PA, Brazil \\ ${ }^{4}$ Sococo Agroindústria da Amazônia, Santa Isabel do Pará, PA, Brazil \\ Correspondence: Lucas Faro Bastos, Institute of Agrarian Sciences, Department of Plant Biology and \\ Phytosanity, Universidade Federal Rural da Amazônia, Belém, PA, Brazil. Tel: 55-919-8917-2526. E-mail: \\ lucas.fbufra@gmail.com
}

Received: April 2, 2019

Accepted: June 21, 2019 Online Published: August 31, 2019

doi:10.5539/jas.v11n14p186

URL: https://doi.org/10.5539/jas.v11n14p186

\begin{abstract}
Haplaxius crudus is the primary vector of the phytoplasma that causes the Lethal Yellowing of Coconut, a disease that has become a barrier to the establishment of large coconut plantations in the world. The objective of this study was to determine the spatial distribution pattern and population dynamics of $H$. crudus adults by correlating them with the abiotic factors, such as temperature and rainfall in commercial dwarf coconut palm plantations. Collection of American palm cixiid was carried out using yellow sticky traps fixed to the abaxial part of the coconut leaves. The sampled plants were georeferenced to obtain the geographic coordinates and geostatistical analysis, besides the planialtimetric survey of the experimental plot for the preparation of the map that shows the topographic conformation of the terrain. Insects were found at the study site throughout the year, showing greater abundance in months when the average monthly temperatures and rainfall were not significant. The climatic factors showed a correlation with the total of insects, positive for the temperature, with 0.733 and negative for the precipitation with -0.606 . The spatial distribution of $H$. crudus displayed an aggregate pattern, explained by the spherical model. The infestation focus occurred in the periphery of the plot, near a Brachiaria humidicola pasture. It was concluded that the infestation of the $H$. crudus showed a behavior directly related to the local climatic conditions and the aggregate spatial distribution explained by the spherical model, therefore, forming shrubs with a radius of 154 to $190 \mathrm{~m}$, with areas of influence between 7.45 and 17.80 ha, which coincide with the lower part of the terrain.
\end{abstract}

Keywords: altimetry, American palm cixiid, geostatistics, pest monitoring, kriging

\section{Introduction}

The coconut (Cocos nucifera L.) is a monocotyledon plant belonging to the Arecaceae family. This plant exhibits arboreal behavior, with a stem-like trunk. It is originated of the islands in Southeast Asia. Its cultivation is considered an agricultural activity of great importance, mainly in countries in economic development (Harries \& Clement, 2013). The state of Pará is the largest coconut producer in the Brazilian North region and the fourth largest in Brazil, with a planted area of 18,595 ha and production of 173,788 tons of fruits (IBGE, 2018; FAOSTAT, 2016).

A sharp drop was found in the worldwide coconut productivity caused by the rapid spread of a disease termed Lethal Yellowing. The primary obstacles for controlling such disease are its rapid progress and high lethality, besides the lack of studies on the transmission (Ramos-Hernández et al., 2018). The first symptoms of the disease are the abortion of the fruits, followed by the blackened color, resulting in the reduction of seed viability. The visible symptoms are the necrosis of the inflorescences and the so-called yellowing or bronzing of the leaves. 
These leaves undergo dehydration processes, progressing towards their falling (Bertaccini et al., 2014). Death in coconut palms and other palm trees may occur approximately four months after the onset of the first symptoms (Meyerdirk \& Hart, 1982; Gurr et al., 2016). The disease is caused by a phytopathogen that present cell composition similar to the bacteria, belonging to the group of phytoplasmas, whose translocation within the plant is through the phloem, and the transmission from one plant to another occurs by the activity of a vector (Waters \& Hunt, 1980; Abeysinghe et al., 2016), which is the Haplaxius crudus Van Duzee 1907 (Hemiptera: Auchenorrhyncha: Cixiidae). The disease is spread by H. crudus, considered the main vector insect. This fact does not exclude the possibility of transmission through other sap-sucking insects, like other species of American palm cixiid, which is caused by the habit of feeding on the floemamatic sap, a local where its causative phytoplasma is found (Wheeler \& Wilson, 2014; Narváez et al., 2018).

According to Tsai and Kirsch (1978), Howard and Wilson (2001), and Howard (2012), the nymphs of this hemipterus feed on the sap elaborated in the roots of some grass species and some Cyperaceae, with an average development time of approximately 80 days at $24{ }^{\circ} \mathrm{C}$ and 52 days at $30{ }^{\circ} \mathrm{C}$ under laboratory conditions in experiments of studies conducted in Florida. In the adult stage, it can be found in the abaxial part of the palm leaves (Gitau et al., 2009). They feed on the lower parts of the leaves, where they also find shelter, or in partially hidden parts of the host plants close to the soil (Kramer, 1979; Perilla-Henao \& Casteel, 2016). Several control methods can effectively carry out the populational reduction or even the extinction of the vector, $H$. crudus. These include especially chemical and cultural controls, with the removal or replacement of the forage species occurring at the site of infestation and surroundings, aiming at restricting the reproductive activity and initial development of the pest (Pardey \& Arango, 2016).

In such cases, geostatistics becomes an excellent tool for the search of patterns in the form of distribution of many insect pests in different cultures or even in aid of the prevention of possible infestations, where the most proper form of management can be carried out using the results achieved in the study. Several works in this line of study such as those of Fernandes et al. (2003), Dinardo-Miranda et al. (2007), Trindade et al. (2017), and Farias et al. (2018) have been carried out based on the use of this tool as an essential aid to integrated pest management. For the implementation of sustainable management and to reduce costs with the use of pesticides, it is paramount to master the knowledge regarding the population dynamics and spatial and temporal distribution of insect-pests in commercial areas of large crops. This information provides greater precision to the adopted phytosanitary control strategy, controlling the direct problem in the infestation focus (Dal Prá et al., 2011). Therefore, geostatistical analysis through incidence maps and distribution of insects that cause damage to monoculture sites provides a great help to control methods, granting them greater efficacy (Duarte et al., 2015). The possibility of the dissemination of Lethal Yellowing throughout South America is a reality that concerns large coconut farmers in Brazil. Hence, there is a need to use new phytosanitary monitoring technologies to prevent this disease. Therefore, the objective of this study was to study the spatial distribution and the annual population fluctuation of $\mathrm{H}$. crudus in commercial dwarf coconut plantation area, using geostatistics as an analysis tool.

\section{Material and Methods}

\subsection{Experimental Area}

The study was carried out in commercial areas planted with Brazilian dwarf coconut located at $01^{\circ} 13^{\prime} 40.16^{\prime \prime} \mathrm{S}$ and $48^{\circ} 02^{\prime} 54.35^{\prime \prime} \mathrm{W}$, (Figure 1) using aspacing of $7.5 \mathrm{~m}$. The region is characterized by high rainfall rates, with values up to $3,000 \mathrm{~mm}$ and average relative humidity of approximately $80 \%$. The climatic classification according to Köppen-Geiger is of the Afi type (Sema, 2017), in which the rainy season occurs from January to May and the dry season is from June to December. It also displays secondary vegetation of the Capoeira type with foci of pastures. The most predominant soil is the quartzarenic Neosol, with adequate drainage and high weathering levels (Embrapa, 2006). 


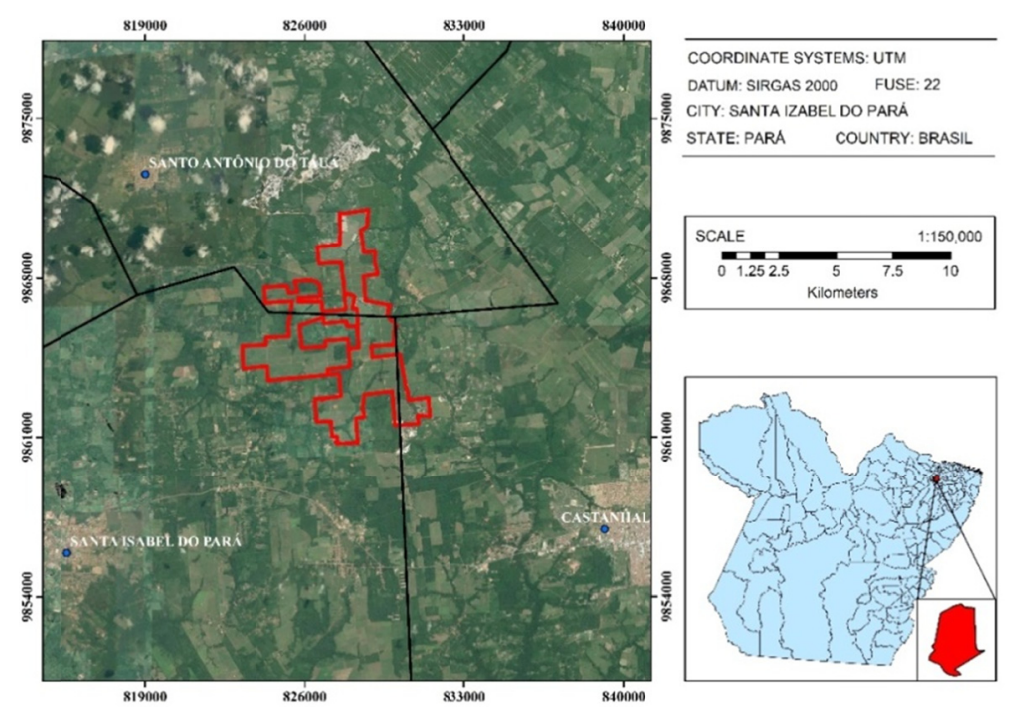

Figure 1. Study area map - Eastern Amazon, Brazil

\subsection{Experimental Design}

In order to select the study area, a preliminary survey of the aerial entomofauna was carried out in 8 plots with different environments, where the results showed a high incidence of $H$. crudus in the vicinity of a water body, which comprised 3 out of the 8 plots, among them one was chosen at random.

The selected area had 19.21 ha with 6-year-old plants, near a dam and areas with Brachiaria humidicola (Rendle) Schweik. The meteorological parameters, such as rainfall $(\mathrm{mm})$ and temperature $\left({ }^{\circ} \mathrm{C}\right)$, were obtained from the meteorological station owned by Sococo Agroindústrias da Amazônia.

Forty yellow sticky traps in the $23 \times 28 \mathrm{~cm}$ (Mark ISCA) were installed. They wereset at the base of the canopies of the coconut palms at $1.50 \mathrm{~m}$ from the ground and arranged in $60 \times 78 \mathrm{~m}$ so that we could obtain the best possible representativeness, as described by Roberto et al. (1997). The taxonomic identification was performed using a stereoscopic microscope and dichotomous keys described by Triplehorn and Johnson (2015) and Rafael et al. (2012). For confirmation of the species, some specimens were selected and sent to the Research Center, Embrapa Tabuleiros Costeiros, a pioneer of finding the vector insect in Brazil (Silva et al., 2019).

Traps were installed every fortnight over a year (October 2017 to September 2018). After collection, the traps were conditioned in transparent plastic bags and stored in a cold room at $5^{\circ} \mathrm{C}$, for later quantification and taxonomy.

\subsection{Georeferencing and Planialtimetric Survey of the Study Area}

Each plant that received a trap georeferenced within the Geographic Information System (GIS), which is based on the Latitude and Longitude crossing. Through this information, one can generate specific geographical positions. The points generated by the coordinates were transformed into UTM (Universal Transverse of Mercator) according to the rectangular system. In the geo-referencing, the Garmin GPS navigation device, model Montana 680 was used (Farias et al., 2002)

A survey of the altimetry of the experimental plot was carried out using the Trimble Geostatic GPS apparatus, model R6, with a $3 \mathrm{~mm}+0.1 \mathrm{ppm}$ RMS precision. For the execution of the areascanning, 30 points were collected, out of which 1 point was from each of the vertices of the plot was tracked. Regarding the preparation of the digital map with more precise information, the data obtained were processed in the Platform IBGE-PPP (Precision Point Processing). The values of the coordinates, in Northing, Easting and Altitude UTM of each sampling point were obtained so that they all belonged to the spindle 22 . The minimum curvature interpolator, which is a digitized terrain construction algorithm, was used to the construction of the digitized map of the plot and for quotas obtaining (Press et al., 1988).

The scanned map of each point of the traps was carried out using SURFER 14.0 software (Brandão, 2018) (Figure 2). 


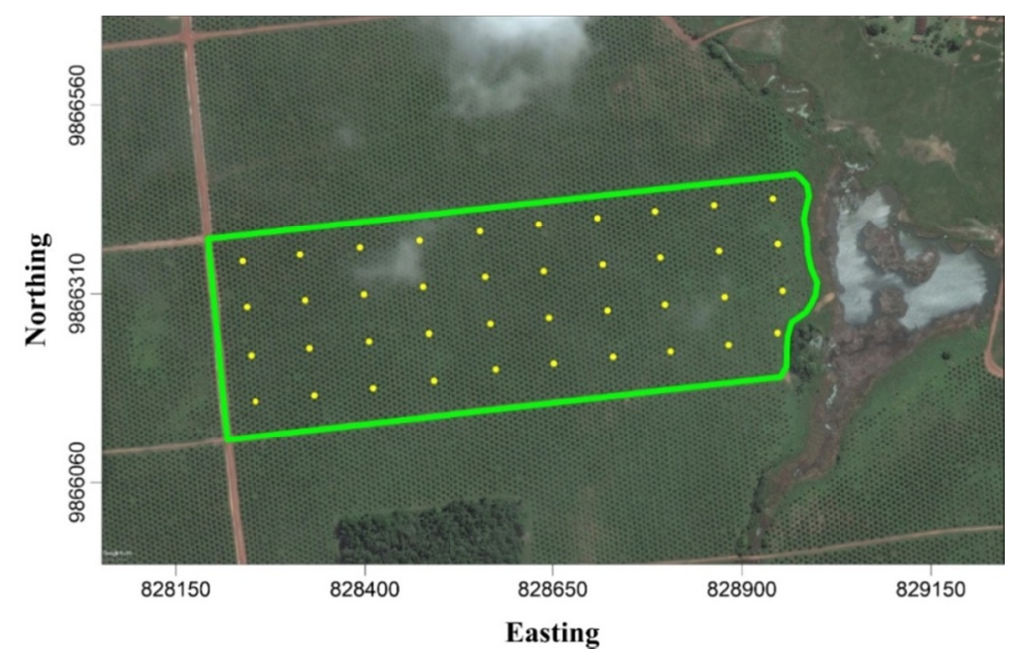

Figure 2. Arrangement of the adhesive traps for the capture of H. crudus in a commercial coconut plantation area, Eastern Amazon, Brazil

\subsection{GeostaticAnalysis}

The semivariograms were adjusted for each of the twelve evaluation months, and then the Kriging maps were made (Vieira et al., 1983). The regionalized variable $\mathrm{Z}$ considered in the study was the number of $H$. crudus adults caught in the adhesive traps, which varied according to the geographical positions determined by the variables longitude $(\mathrm{X})$ and latitude $(\mathrm{Y})$. The spatial dependence between neighboring pairs of points was calculated through the semivariance, estimated by Equation 1:

$$
\gamma^{*}(h)=\frac{1}{2 N(h)} \Sigma_{i=1}^{N(h)}\left[Z\left(X_{i}\right)-\left(X_{i}+h\right)\right]^{2}
$$

Where, $\gamma(h)$ is the semivariance calculated by the distance $h ; N(h)$ is the total number of traps analyzed, which are separated by a distance $h$. In the case of spatially dependent variables, the values $\left[Z\left(x_{i}\right)-Z\left(x_{i}+h\right)\right] 2$, increase until reaching the point of stability (Farias et al., 2002b).

The parameters established for theanalysis of the semivariograms were the plateau $(\mathrm{C} 0+\mathrm{C} 1)$, the nugget effect $(\mathrm{C} 0)$ and the range $(a)$. The plateau is the value of the semivariogram corresponding to its range. The nugget effect is the semivariance between adjacent pairs of points and the range measures the maximum distance that may exist from the spatial dependence. The spatial dependence index (SDI) $k(\mathrm{C} 0 /(\mathrm{C} 0+\mathrm{C} 1)$ ratio) of each evaluation was also calculated in this study. It is classified as weak spatial dependence SDI $>75 \%$, moderate $25 \% \leq \mathrm{SDI} \leq 75 \%$ and strong SDI $<25 \%$ (Cambardella et al., 1994; Landim, 1998; Farias et al., 2004; Pinho et al., 2016).

For each month of sampling, the experimental semivariograms were made, and the best mathematical models were evaluated, taking into account the refining of the adjustment and its value of Determination Coefficient in which Linear, Exponential, Gaussian and Spherical models stood out (Journel \& Huijbregts, 2003). After obtaining the appropriate models, it is possible to make maps by using the ordinary Kriging method, to observe the incidence and the spatial arrangement of the insect in the experimental plot, through the interpolation methodology (Vieira et al., 1983). For the calculation, the ordinary kriging estimator was used, Equation 2:

$$
Z^{*}\left(x_{0}\right)=\sum_{i=1}^{N} \lambda i Z\left(x_{i}\right)
$$

Where, $Z^{*}$ was the estimate for the location, and $x_{0}$ was the linearly combined values of the neighboring measures. $N$ symbolized the number of measured values related to the estimate, $\lambda i$ was the moderation associated with the measured values. In this method, the weights were calculated under two restriction conditionals: where the variance of what is estimated is as minimum as possible and that the estimator does not present a tendency or inclination (Journel \& Huijbregts, 2003).

The most adequate model to the parameters was selected through standardization and adjustment of the data, shown in Equation 3:

$$
\gamma(\mathrm{h})=\{\mathrm{C} 0+\mathrm{C} 1 \cdot \operatorname{Modelo}(\alpha)\}
$$


Where, $\mathrm{C} 0$ was the minimum semivariance, $(\mathrm{C} 0+\mathrm{C} 1)$ was the maximum semivariance, $\alpha$ was the aggregation range, and $h$ was the distance that separates the pairs of points (Yamamoto \& Landim, 2013).

The significance of the Pearson's correlations of the population means of the insects and the average annual and monthly rainfalls was performed using the Student's T-test at $p>0.05$. EXCEL 2013 and STATISTICA 8.0 were the software used in the study.

\section{Results}

A total of $850 \mathrm{H}$. crudus specimens were collected over the complete collection period. A reduction was observed in the number of insects according to the rise in the rainfall and temperature (Figure 3). In December 2017 and September 2018, the highest population peaks of the insect were recorded, totaling 170 and 212 respectively. The lowest quantities were obtained in February and May 2018, with only 2 and 3 specimens.

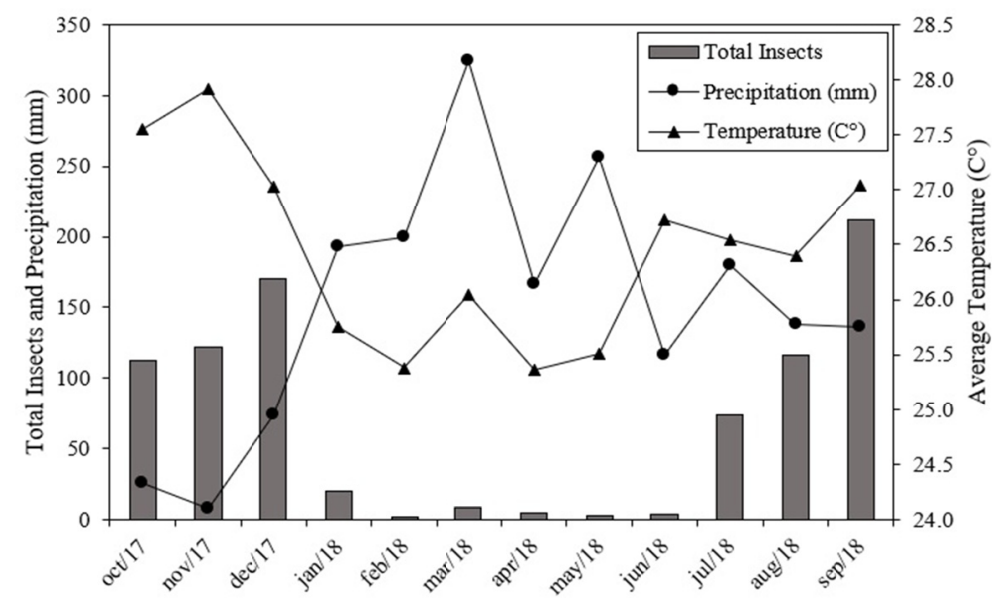

Figure 3. Monthly population fluctuation of H. crudus collected in green dwarf coconut plantation in Brazil, rainfall, and temperature. Eastern Amazon, Brazil

October, November and December 2017 and June, August and September 2018 showed the lowest average rainfall of $72.6 \mathrm{~mm}$. November displayed the most critical rainfall in the evaluated period, only $8 \mathrm{~mm}$. In January, February, March, April, May, and July, the average was $220 \mathrm{~mm}$, directly affecting the occurrence of insects (Figure 3).

It was verified that the population dynamics of $H$. crudus had a strong relationship with the monthly meteorological variables, rainfall, and temperature. The population of $H$. crudus reduced as the amount of rainfall raised, and the temperature decreased. Pearson's correlation between the monthly average of insects and the accumulated rainfall value per month showed a value of $-0.606(\mathrm{p} \geq 0.05)$, which indicated a negative correlation between the factors. The significant value of $0.733(\mathrm{p} \geq 0.05)$ indicated a positive correlation, which was obtained when the average monthly temperature variable was correlated with the monthly average of insects (Figures 4 and 5). 


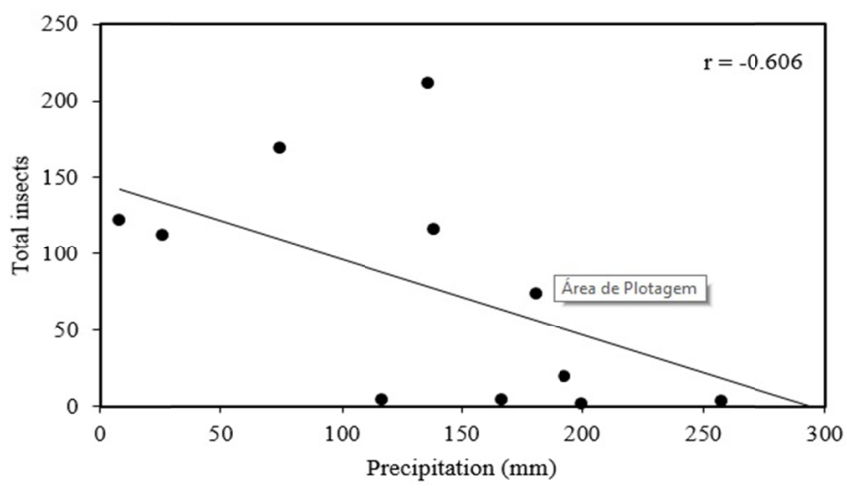

Figure 4. Correlation between the monthly total of Haplaxius crudus individuals collected in commercial green dwarf coconut areas of Brazil and the average monthly rainfall. Eastern Amazon, Brazil

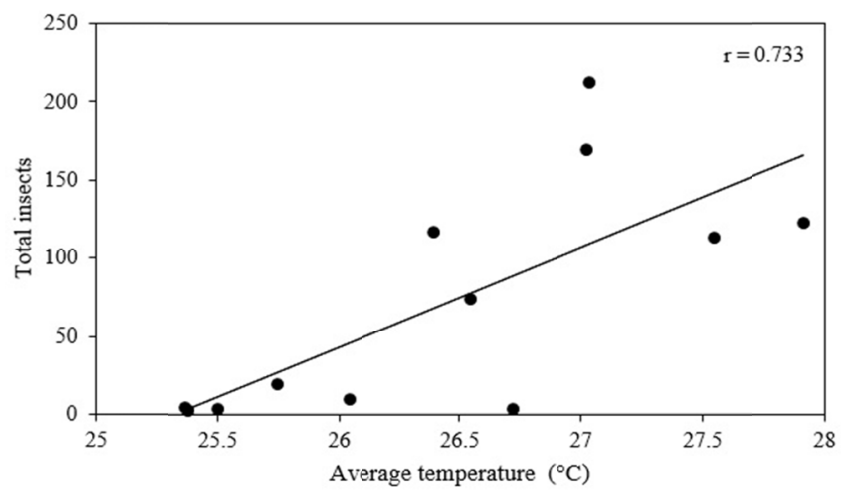

Figure 5. Correlation between the monthly total of Haplaxius crudus individuals collected in commercial green dwarf coconut areas of Brazil and the average monthly temperature. Eastern Amazon, Brazil

It was observed that the minimum range value was at 154 meters of distance with 7.45 ha of area. It was influenced by insect infestation, confirming that the network formed by the spatial distribution of the traps in the field was considered satisfactory, therefore, demonstrating that an aggregated spatial distribution. However, the maximum range was 238 meters with an area of influence of 17.80 ha (Table 1).

Table 1. Semivariogram parameters, range area, coefficient of determination $\left(\mathrm{R}^{2}\right)$, spatial dependence index and experimental model for geostatistics analysis. Eastern Amazon, Brazil

\begin{tabular}{|c|c|c|c|c|c|c|c|c|}
\hline \multirow{2}{*}{ Evaluation month } & \multicolumn{3}{|c|}{ Parameters } & \multirow{2}{*}{ Reach Area (ha) } & \multirow{2}{*}{$\mathrm{R}^{2}$} & \multirow{2}{*}{$k$} & \multirow{2}{*}{ Model } & \multirow{2}{*}{$\begin{array}{l}\text { Degree of } \\
\text { Dependency }\end{array}$} \\
\hline & $\mathrm{CO}$ & $\mathrm{C} 1$ & $\mathrm{a}(\mathrm{m})$ & & & & & \\
\hline Oct/17 & 8 & 12.7 & 175 & 9.62 & 0.97 & 0.386 & Spherical & Moderate \\
\hline Nov/17 & 0 & 94 & 160 & 8.04 & 0.95 & 0.000 & Spherical & Weak \\
\hline Dec/17 & 0 & 19.7 & 190 & 11.34 & 0.99 & 0.000 & Spherical & Weak \\
\hline $\operatorname{Jan} / 18$ & \multicolumn{8}{|c|}{ Without adjustment } \\
\hline $\mathrm{Feb} / 18$ & \multicolumn{8}{|c|}{ Without adjustment } \\
\hline $\mathrm{Mar} / 18$ & \multicolumn{8}{|c|}{ Without adjustment } \\
\hline Apr $/ 18$ & \multicolumn{8}{|c|}{ Without adjustment } \\
\hline May/18 & \multicolumn{8}{|c|}{ Without adjustment } \\
\hline Jun/18 & \multicolumn{8}{|c|}{ Without adjustment } \\
\hline $\mathrm{Jul} / 18$ & 0 & 14.2 & 238 & 17.80 & 0.99 & 0.000 & Spherical & Weak \\
\hline Aug/18 & 6.8 & 15.4 & 154 & 7.45 & 0.95 & 0.306 & Spherical & Moderate \\
\hline Sep/18 & 10 & 136 & 190 & 11.34 & 0.97 & 0.068 & Spherical & Weak \\
\hline
\end{tabular}

Note. Calculated by $\pi \cdot r^{2}$, in which $\pi=3.14159$ and $\mathrm{r}=\mathrm{a}$; Relationship between $\mathrm{C} 0 /(\mathrm{C} 1+\mathrm{C} 0)$. 
Among the mathematical models most applied to data referring to biotic parameters, the spherical was the one that offered the best fit to the experimental semivariograms. These showed a coefficient of determination $\left(\mathrm{R}^{2}\right)$ that oscillated between the values of 0.95 to 0.99 . The parameters obtained by the spherical model in relation to the occurrence of the H. crudus insect presented all coefficients of determination $\left(\mathrm{R}^{2}\right)$ greater than 0.90 (Figure 6).

The adjustment was performed using the spherical model for each of the 12 months; however, the rainy season months, from January to June, did not allow model adjusting due to the small number of insects captured, that is, because these months did not show a significant number of specimens.
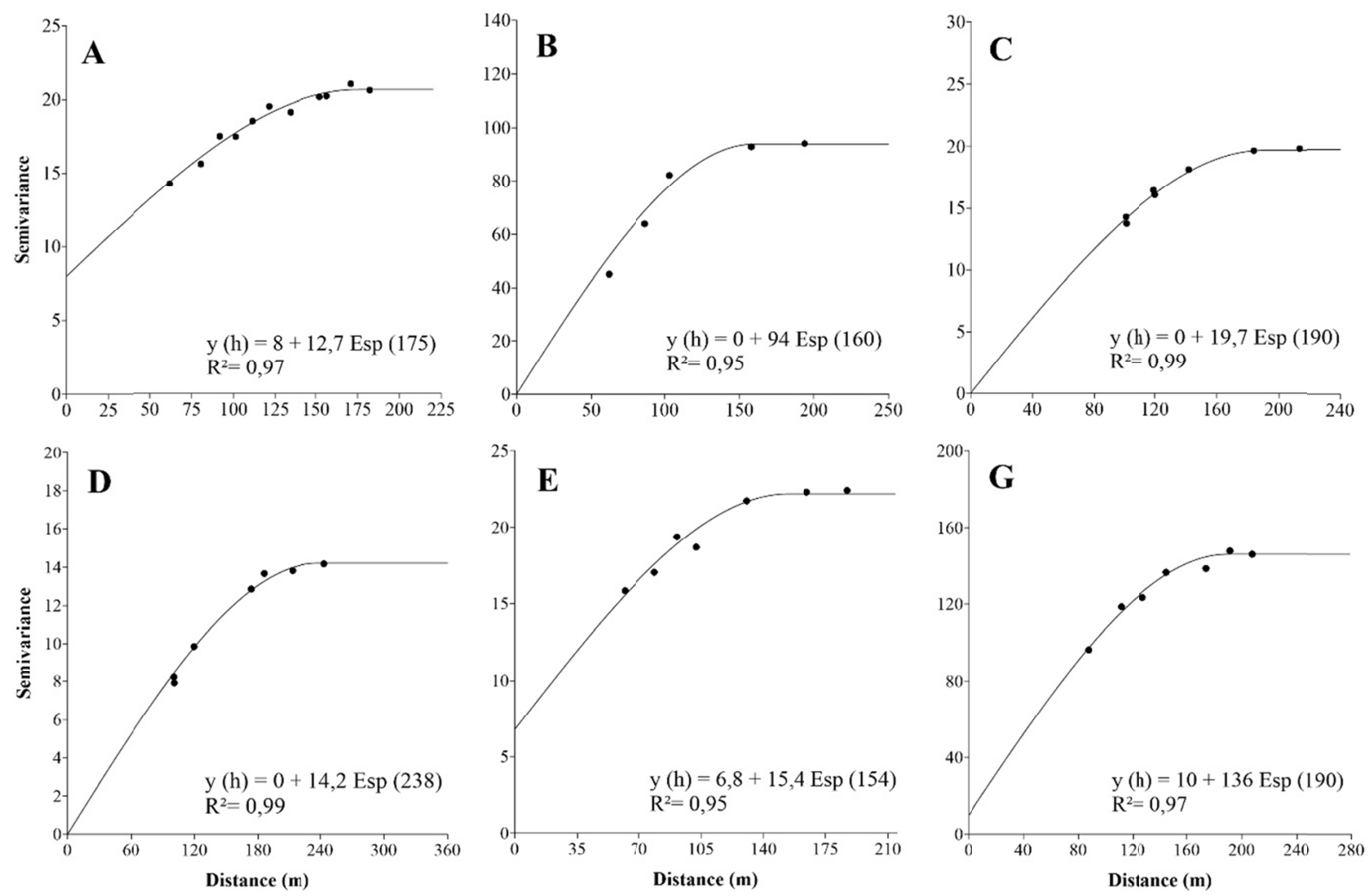

Figure 6. Semivariograms related to Haplaxius crudus infestation in dwarf coconut commercial crops in Brazil, in relation to October (A), November (B), December (C) 2017 and July (D), August (E) and September (F) 2018.

Eastern Amazon, Brazil

It was observed that from the surface maps, the infestation density and the positioning of the insects had undergone small variations over time and change of climatic conditions. However, they were usually found to be coincidentally concentrated between the two lower levels of the area, 12 and $13 \mathrm{~m}$, respectively, where the area was characterized by humid soil and small foci of $B$. humidicola grass. In addition, the maps showed areas of aggregation of the pest, with the formation of a bush (Figures 7 and 8). 

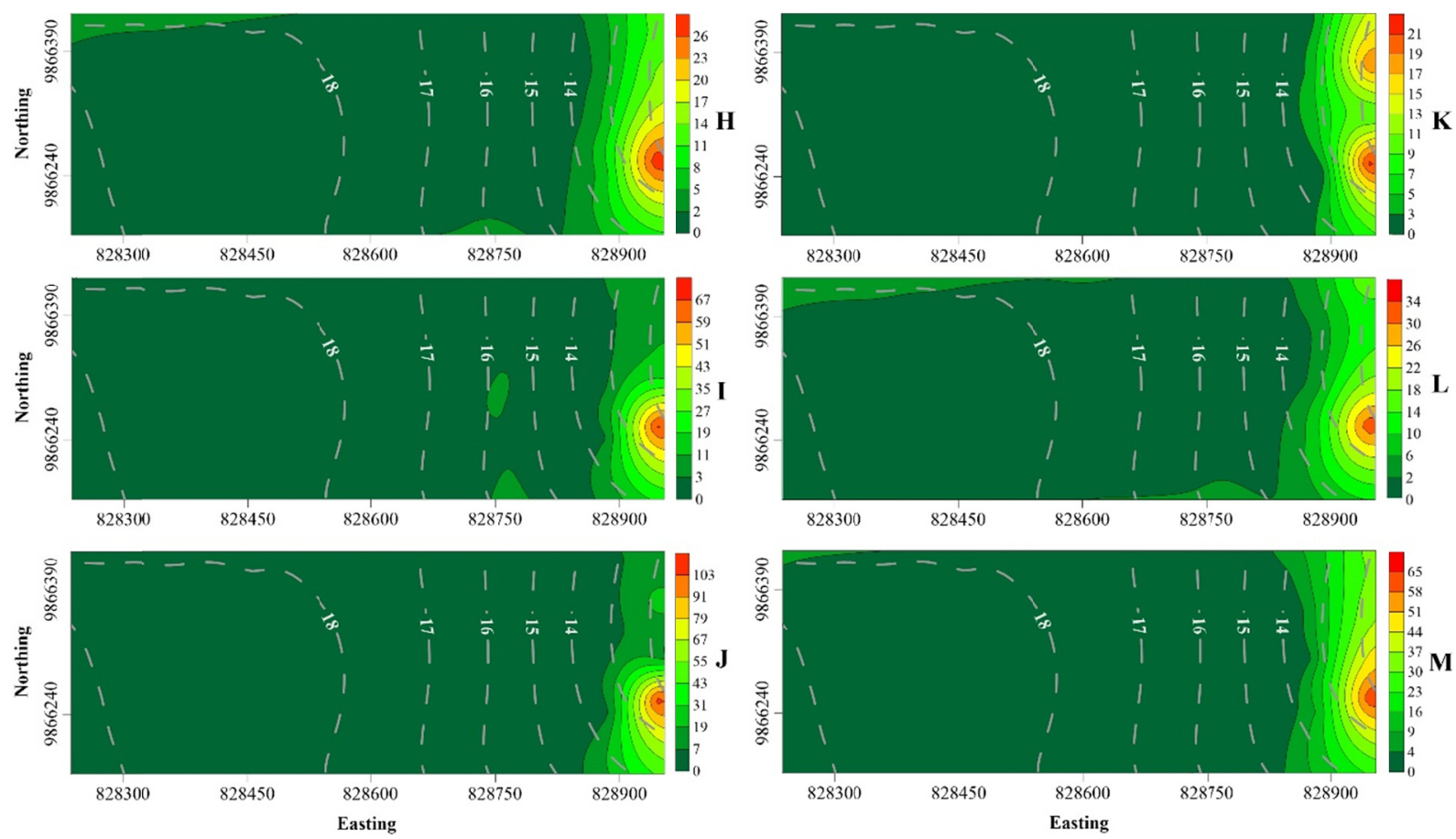

Figure 7. Kikring map of the spatial distribution of Haplaxus crudus and altimetry (dotted line) in a green dwarf coconut commercial crop in Brazil in October (H), November (I), December (J) 2017 and July (K), August (L) and September (M) 2018, Eastern Amazon, Brazil.

\section{Discussion}

The use of dispersion graphs (Figures 4 and 5), which shows a positive significant correlation between $H$. crudus population and the temperature and negative one for precipitation, the influence of biotic and abiotic factors has become evident. Factors already observed by Paradell et al. (2014), when reporting that American palm cixiid community suffers an increase in its population when the temperature, photoperiod, and air humidity factors are simultaneously raised. Although those variables are intrinsic, they are not the only ones that affect the population dynamics of these insects. Indeed, predation, interspecific competition, parasitism, among others seem to act in conjunction with meteorological factors, shaping the species distribution. The $H$. crudus population fluctuation is directly related to the climatic variations of the environment. The adults usually may be found all over the year in the abbatial portion of palm leaves, but they are more abundant in periods with lower rainfall (Moreno et al., 2014). Such a statement is shown in this study for H. crudus.

Climatological factors strongly influence the natural development of phytophagous insects, and these factors intrinsically interfere in the processes of oviposition, feeding, growth, and reproduction. In many cases, variables such as rainfall and temperature affect the population dynamics of insect pests and non-pests (Rahmathulla et al., 2012). Such fact confirms the behavior of $H$. crudus in this study, as it is a heterovoltin species, that is, the number of generations being affected by temperature, which is in agreement with what was reported by Halbert et al. (2014). Results similar to those obtained in this work were also shown by Silva et al. (2018), when they evaluated the seasonal variation of community of the suborder Auchenorrhyncha in Brazilian dwarf coconut trees, finding similarities to the present study, especially when the relative contribution of the abiotic factors in the explanation of the composition of these communities, in which H. crudus is inserted, because the authors demonstrated that insects of this suborder are more abundant immediately after the months that presented a high amount of rainfall and when the average monthly temperatures suffered a small raise.

Some studies have already shown this behavior for other sucking insects. Regarding the results obtained with the spatial distribution of $H$. crudus, anaggregate behavior was found. Generally, sucking insects of the suborder Auchenorryncha present this type of pattern. Some studies have already demonstrated this behavior for other sucking insects. It should be stressed the works of Oliveira et al. (2016), when studying the spatial behavior of Empoasca kameri adult insects (Ross \& Moore, 1957) (Hemiptera: Cicadellidae) in physic nut and that of Leal et al. (2010), with plants showing greening disease (Huanglongbing/HLB) which is transmitted by Diaphorina citri 
Kuwayama (Hemiptera: Psyllidae), and also obtained aggregate distribution. This model of distribution is the one that best suits the spatial behavior of these insects since this shows the foci of infestation in the form of concentric shrubs that tend to expand in all directions according to the population growth of the pest. By using the kriging maps of the spatial arrangement of $H$. crudus it was possible to observe a preference of the insect population on the periphery of the plot, closer to the pasture, where B. humidicola can be found. Some authors, such as Hernandez et al. (2018), studied the weeds used by $H$. crudus in a coconut pathosystem in southern Mexico and found that $B$. humidicola is one of the leading host species of the pest and suggested that the use of integrated management should be considered important when this grass is found in areas of coconut production. Also, after hatching of $H$. crudus nymphs, they descend to the soil surface and develop in the roots of the grass. Humid locals and grass with longer foliage are the most preferred locals (Howard, 2015), a fact confirmed in this study, as a greater aggregation of American palm cixiid were found in the lower and humid areas. Considering that the location of the point where the greatest infestation practically remains unchanged, it is suggested that this is the result of the dispersal behavior of this pest that occurs mainly through wind currents due to the low capacity of flight.

The altimetric survey for the analysis of the behavioral pattern of spatial distribution of the displayed results that demonstrate a clear preference for the areas of lower altitude, where there is a greater accumulation of moisture in the soil, which makes this environment conducive to the development of the insect. It should be noted that individuals of the Auchenorryncha suborder are necessarily sap-suckers that in their initial development depend on the environmental conditions where they are living in such as in the experiment by Latini et al. (2019), who demonstrated that the control of nymph-stage $H$. crudus should be carried out after hatching and before the first stages of larva, when they depend directly on the humidity. Therefore, reinforcing the need for constant phytosanitary monitoring in areas with similar characteristics.

\section{References}

Abeysinghe, S., Abeysinghe, P. D., Silva, C. K., Udagama P., Warawichanee K., Aljafar N., ... Dickinson, M. (2016). Refinement of the taxonomic structure of 16srxi and 16srxiv phytoplasmas of gramineous plants using multilocus sequence typing. Plant Disease, 100(10), 2001-2010. https://doi.org/10.1094/PDIS-0216-0244-RE

Arango, M., Saavedra, C. M., \& Martínez, G. (2012). Efecto del color de las trampas en el monitoreo de adultos de Haplaxius (Myndus) crudus. Palmas, 33(4), 53-61.

Bertaccini, A., Duduk, B., Paltrinieri, S., \& Contaldo, N. (2014). Phytoplasmas and phytoplasma diseases: A severe threat to agriculture. American Journal of Plant Sciences, 5(12), 1763-1788. https://doi.org/10.4236/ ajps.2014.512191

Brandão, A. D. S., Farias, P. R. S., Dionisio, L. F. S., Tinôco R. S., Silva, A. G., \& Silva T. A. F. (2017). Spatial and temporal distribution of Opsiphanes invirae (Lepidoptera: Nymphalidae) in oil palm, Pará State, Brazil. Revista Brasileira de Ciências Agrárias, 12(4), 464-469. https://doi.org/10.5039/agraria.v12i4a5479

Cambardella, C. A., Moorman, T. B., Novak, J. M., Parkin, T. B., Karlen, D. L., Turco, R. F., \& Konopka, A. E. (1994). Field-scale variability of soil properties in Central Iowa soils. Soil Science Society of America Journal, 58(5), 1501-1511. https://doi.org/10.2136/sssaj1994.03615995005800050033x

Dal Prá, E., Guedes, J. V. C., Cherman, M. A., Jung, A. H., Silva, S. J. P., \& Ribas, G. G. (2011). Uso da geoestatística para caracterização da distribuição espacial de larvas de Diloboderus abderus. Ciência Rural, 4l(10), 1689-1694. https://doi.org/10.1590/S0103-84782011001000002

Dinardo-Miranda, L. L., Vasconcelos, A. C. M., Vieira, S. R., Fracasso, J. V., \& Grego, C. R. (2007). Uso da geoestatística na avaliação da distribuição espacial de Mahanarva Fimbriolata em cana-de-açúcar. Bragantina, 66, 449-455. https://doi.org/10.1590/S0006-87052007000300011

Duarte, F., Calvo, M. V., Borges, A., \& Scatoni, I. B. (2015). Geostatistics and Geographic Information Systems to Study the Spatial Distribution of Grapholita molesta (Busck) (Lepidoptera: Tortricidae) in Peach Fields. Neotropical Entomology, 44(4), 319-327. https://doi.org/10.1007/s13744-015-0288-3

Embrapa. (2006). Conceito e Definição das Classes de $1^{\circ}$ Nível (ordens). In H. G. Santos, P. K. T. Jacomine, L. H. C. Anjos, V. A. Oliveira, M. R. Coelho, J. F. Lumbreras, \& T. J. F. Cunha (Eds.), Sistema Brasileiro de Classificação de Solos (2nd ed., pp. 76-92). Brasília: Embrapa-SPI.

FAOSTAT. (2016). Crops. Food and Agriculture Organization. Retrieved from http://www.fao.org/faostat/ en/\#data/QC 
Farias, P. R. S., Harada, A. Y., Filgueiras, C. C., Lima, B. G., Sales, T. M., Silva, A. G., \& Souza, B. H. S. (2018). Mapping Azteca barbifex Forel (Hymenoptera: Formicidae) dispersal in georeferenced Orange (Citrus sinensis [L.] Osbeck) orchard in the Eastern Amazon, Brasil. Insectes Sociaux, 65(2), 345-350. https://doi.org/10.1007/s00040-018-0610-2

Farias, P. R. S., Roberto, S. R., Lopes, J. R. S., \& Perecin, D. (2004). Geoestatiscal characterization of the spatial distribution of Xylella fastidiosa sharpshooter vectors on citrus. Neotropical Entomology, 33(1), 013-020. https://doi.org/10.1590/S1519-566X2004000100004

Farias, P. R. S., Sánchez-Vila, X., Barbosa, J. C., Vieira, S. R., Ferraz, L. C. C. B., \& Solís-Delfin, J. (2002). Using geostatistical analysis to evaluate the presence of Rotylenchulus reniformis in cotton crops in Brazil: Economic implications. Journal of Nematology, 34(3), 232-238.

Fernandes, M. G., Busoli, A. C., \& Barbosa, J. C. (2003). Distribuição espacial de Alabama argillacea (Hübner) (Lepidoptera: Noctuidae) em Algodoeiro. Neotropical Entomology, 32(1), 107-115. https://doi.org/10.1590/ S1519-566X2003000100017

Gitau, C. W., Gurr, G. M., Dewhurst, C. F., Fletcher, M. J., \& Mitchell, A. (2009). Insect pests and insect-vectored diseases of palms. Australian Journal of Entomology, 48(4), 328-342. https://doi.org/ 10.1111/j.1440-6055.2009.00724.X

Gurr, G. M., Johnson, A. C., Ash, G. J., Wilson, B. A. L., Ero, M. M., \& Pilotti, M. S. (2016). Coconut Lethal Yellowing Diseases: A Phytoplasma Threat to Palms of Global Economic and Social Significance. Frontier Plant Science. https://doi.org/10.3389/fpls.2016.01521

Harries, H. C., \& Clement, C. R. (2013). Long-distance dispersal of the coconut palm by migration within the coral atoll ecosystem. Annals of Botany, 113, 565-570. https://doi.org/10.1093/aob/mct293

Hernández, E. R., Alejandro, M. A. M., García, C. F. O., Salín, C. O., Gordillo, J. M. L., \& Soto, S. S. (2018). The coconut pathosystem: Weed hosts of nymphs of the american palm cixiid Haplaxius crudus (Hemiptera: Fulgoroidea). Journal of Natural History, 52(5-6), 255-268. https://doi.org/10.1080/00222933.2017. 1420832

Howard, F. W., \& Wilson, M. R. (2001). Hemiptera: Auchenorrhyncha. In F. W. Howard, D. R. M. Moore, R. M. Giblin-Davis, \& R. G. Abad (Eds.), Insects on Palms London (pp. 128-160). Nova Iorque: CAB Publishing. https://doi.org/10.1079/9780851993263.0000

Howard, F. W. (2015). American palm cixiid-Mynduscrudus Van Duzee. Featured Creatures. USA: University of Florida.

IBGE (Instituto Brasileiro de Geografia e Estatística). (2016). Levantamento Sistemático da Produção Agrícola (LSPA).

Journel, A. G., \& Huijbregts, J. C. H. (2003). Mining geoestatistics (p. 600). New York: Blackburn Press.

Kramer, J. P. (1979). Taxonomic study of the planthopper genus Myndus in the Americas (Homoptera: Fulgoroidea: Cixiidae). American Entomology Society, 105(3), 301-389.

Landim, P. M. B. (1998). Análise estatística de dados geológicos (p. 226). São Paulo: UNESP.

Latini, A., Foxi, C., Borfecchia, F., Lentini, A., Cecco, L., Iantosca, D., \& Mariani, S. (2019). Tacking the vector of Xylellafastidiosa: Geo-statistical analysis of long-term field observations on host plants influencing the distribution of Phylaenus spumarius nymphs. Environmental Science and Pollution Research, 1-14. https://doi.org/10.1007/s11356-018-3870-5

Leal, R. M., Barbosa, J. C., Costa, M. G., Belasque Júnior, J., Yamamoto, P. T., \& Dragone, J. (2010). Distribuição espacial de Huanglongbing (Greening) em citros utilizando a geoestatística. Revista Brasileira de Fruticultura, 32(3), 808-818. https://doi.org/10.1590/S0100-29452010005000077

Mello, A. P. O. A., Bedendo, I. P., \& Camargo, L. E. A. (2007). Identidade molecular dos fitoplasmas associados aos enfezamentos do tomateiro e da berinjela com base na análise do gene $16 \mathrm{~S}$ rDNA. Summa Phytopathologica, 33(3), 258-263. https://doi.org/10.1590/S0100-54052007000300008

Meyerdirk, D. E., \& Hart, W. G. (1982). Survey of Auchenorrhyncha (Insecta: Homoptera) associated with the Canary Island date palm in Southern Texas. Florida Entomologist, 65(3). https://doi.org/10.2307/3494305 
Moreno, L. J. S., Pardey, A. E. B., Estupiñán, G. A. R., Gutiérrez, H. J., \& Perilla, J. A. M. (2014). Variación en las poblaciones de Haplaxius crudus, vector de la Marchitez letal, en plantaciones de palma de aceite en Colombia. Ceniavances 178. Bogotá: Cenipalma.

Narváez, M., Vázquez-Euán, R., Harrison, N. A., Nic-Matos, G. N., Julia, J. F., Dzido, F. L., ...Oropeza, C. (2018). Presence of 16SrIV phytoplasmas of subgroups A, D and E in planthopper Haplaxius crudus Van Duzee insects in Yucatán, Mexico. Biotech, 61(8). https://doi.org/10.1007/s13205-018-1094-5

Nipah, J. O., Jones, P., \& Dickinson, M. J. (2007). Detection of lethal yellowing phytoplasma in embryos from coconut palms infected with Cape St Paul wilt disease in Ghana. Plant Pathology, 56, 777-84. https://doi.org/10.1111/j.1365-3059.2007.01623.x

Oliveira, M. D. G., Fernandes, M. G., Mota, T. A., \& Oliveira, H. N. (2016). Spatial distribution of Empoasca kraemeri (Hemiptera: Cicadellidae) adults in physic nut Jatrophacurcas L. Entomotropica, 31(29), 237-243.

Paradell, S., Defea, B., Dughetti, A., Zárate, A., \& Lenicov, A. M. M. R. (2014). Diversity of Auchenorryncha (Hemiptera: Cicadellidae) associated with Viciavillosa in Southern Buenos Aires Province, Argentina. Florida Entomologist, 97(2), 674-684. https://doi.org/10.1653/024.097.0247

Pardey, A. E. B., \& Arango, C. M. (2016). Las mejores prácticas para detener el avance de la Marchitez letal (ml) en plantaciones de palma de aceite en Colombia. Revista Palmas, 37, 75-90.

Perilla-Henao, L. M., \& Casteel, C. L. (2016). Vector-borne bacterial plant pathogens: Interactions with hemipteran insects and plants. Frontiers in Plant Science, 7, 1-15. https://doi.org/10.3389/fpls.2016.01163

Pinho, R. C., Farias, P. R. S., Rodrigues, K. C. V., Tinôco, R. S., Santos, A. V. F., \& Marssena, R. T. P. (2016). Distribuição espacial de Rhynchophorus palmarum em palma de óleo no Estado do Pará, Amazônia. Revista de Ciências Agrárias, 59(1), 22-31. https://doi.org/10.4322/rca.2116

Press, W. H., Flannery, B. P., Teukolsky, S. A., \& Vetterling, W. T. (2007). Numerical Recipes in C (3rd ed., p. 1195). New York: Cambridge University Press.

Rafael, J. A., Melo, G. A. R., Carvalho, C. J. B., Casari, S., \& Constantino, R. (2012.). Insetos do Brasil diversidade e taxonomia (p. 810). Ribeirão Preto: Holos Editora.

Rahmathulla, V. K., Kumar, C. M. K., Angadi, B. S., \& Sivaprasad, V. (2012). Association of climatic factors on population dynamics of leaf roller, diaphania pulverulentalis hampson (Lepidoptera: Pyralidae) in mulberry plantations of sericulture seed farm. Psyche: A Journal of Entomology.

Ramos-Hernandéz, E., Torres De La Cruz, M., Oropeza-Salín, C., Ortiz-Garcia, C. F., Lesher-Gordillo, J., \& Magaña-Alejandro, M. A. (2018). Manejo del agroecosistema cocotero, con énfasis en el amarillamiento letal del cocotero (Cocos nucifera L.). Revista Agroproductividad, 11(1), 80-87.

Roberto, S. R., Lima J. E. O., Coutinho, A., Miranda, V. S., \& Carlos E. F. (1997). Avaliação de métodos de monitoramento de cigarrinhas transmissoras da clorose variegada dos citros. Revista Brasileira de Fruticultura, 19(2), 227-233.

SEMA. (2017). Classificação Climática do Pará Método de Köppen.

Silva, F. G., Passos, E. M., Diniz, L. E. C., Farias, A. P., Teodoro, A. V., Fernandes M. F., \& Dollet, M. (2018). Rainfall and coconut accession explain the composition and abundance of the community of potential Auchenorrhyncha phytoplasma vectors in Brazil. Environmental Entomology, 47(2), 318-324. https://doi.org/ 10.1093/ee/nvy010

Silva, F. G., Passos, E. M., Diniz, L. E. C., Teodoro, A. V., Talamini, V., Fernandes, M. F., \& Dollet, M. (2019). Occurrence in Brazil of Haplaxius crudus (Hemiptera: Cixiidae), vector of Coconut Lethal Yellowing. Neotropical Entomology, 4. https://doi.org/10.1007/s13744-018-0663-y

Tsai, J. H., \& Kirsch. O. H. (1978). Bionomics of Haplaxius crudus (Homoptera: Cixiidae). Environmental Entomology, 7(2), 305-308. https://doi.org/10.1093/ee/7.2.305

Trindade, R. B. R., Fernandes, M. G., Oliveira, A. C., \& Martins, P. H. A. (2017). Distribuição espacial de Spodoptera frugiperda (J. E. Smith) (Lepidoptera, Noctuidae) em milho convencional e Bt. Entomobrasilis, Dourados, 10(2), 89-93. https://doi.org/10.12741/ebrasilis.v10i2.683

Triplehorn, C. A., \& Johnson, N. F. (2015). Estudo dos insetos. Tradução da $7^{a}$ edição de Borror and Delong's introduction to the study of insects (2nd ed., p. 809). São Paulo: Cengage Learning. 
Vieira, S. R., Hatfield, J. L., Nielsen, D. R., \& Biggar, J. W. (1983). Geoestatistical theory and application to variability of some agronomical properties. Hilgardia, 51(3), 1-75. https://doi.org/10.3733/hilg.v51n03p075

Waters, H., \& Hunt, P. (1980). The in vivo three-dimensional form of a plant mycoplasma-like organism by the analysis of serial ultrathin sections. Journal of General Microbiology, 116(1), 111-131. https://doi.org/ 10.1099/00221287-116-1-111

Wheeler, A. G., \& Wilson, S. W. (2014). The cixiid planthopper Haplaxius ovatus (ball) (Hemiptera: Fulgoroidea): Association with switchgrass (Panicum virgatum; Poaceae) and new distribution records. Proceedings of the Entomological Society of Washington, 116(3), 358-368. https://doi.org/10.4289/ 0013-8797.116.3.358

Yamamoto, J. K., \& Landim, P. M. B. (2013). Geoestatística conceitos e aplicações (pp. 19-34). São Paulo: Oficina de Textos.

\section{Copyrights}

Copyright for this article is retained by the author(s), with first publication rights granted to the journal.

This is an open-access article distributed under the terms and conditions of the Creative Commons Attribution license (http://creativecommons.org/licenses/by/4.0/). 